\title{
Is Our Safety and Security Guaranteed on University of Cape Coast Campus? Undergraduates Students' Perceptions
}

\author{
Owusu, G. A. ${ }^{1}$, Akoto, J. S. ${ }^{2}$ \& Abnory, M. M. ${ }^{3}$ \\ ${ }^{1}$ School of Business, University of Cape Coast, Cape Coast, Ghana \\ ${ }^{2}$ Registrar's Office, University of Mines and Technology, Tarkwa, Ghana \\ ${ }^{3}$ Directorate of Legal, Consular, and General Services, University of Cape Coast, Ghana. \\ Correspondence: Owusu, G. A., School of Business, University of Cape Coast, Cape Coast, Ghana
}

Received: May 24, 2016

Accepted: September 13, 2016

Online Published: October 7, 2016

doi:10.5430/ijhe.v5n4p75

URL: http://dx.doi.org/10.5430/ijhe.v5n4p75

\begin{abstract}
In higher education like other institutions, safety and security of persons particularly students resident on university campuses remain topical. The limited research conducted on the experiences of university students in Ghana reflects paucity of literature on safety and security on university campuses in Ghana where such issues have been neglected. Yet, there have been numerous instances where students' study lives have been threatened due to acts of burglary and other forms of violent acts. The issue of campus safety is thus crucial and there is the need to pay attention to it. This study is drawing mainly on perceptions of students about safety and security issues in University of Cape Coast (UCC). Working within a case study which used survey design to obtain a comprehensive picture of students' perceptions about their safety and security on campus, the findings showed that students are not satisfied with the overall safety and security on campus particularly in the evenings. The students suggested that building more halls of residence, improving the lighting system on campus, and installing emergency phones across campus, intensifying security presence on campus as well as controlling the number of people that enter the campus are sure ways of ensuring that UCC was safer.
\end{abstract}

Keywords: Higher education, Safety, University campus

\section{Introduction}

In recent times, the safety of university campuses has become an issue of widespread. The issue could be attributed to the higher perception of risk of students due to several high profile cases that are covered by the national media in recent years. It could also be perhaps as a result of the increase in enrollment of students in our universities which is not commensurate with the number of security personnel provided by university authorities on our campuses. Further, the matter has been analysed from the perspective that increases in female enrolments levels could be a factor since women are normally perceived as vulnerable when it comes to safety and security issues.

Studies conducted by Chekwa, Thomas and Jones (2013); Fernandez (2001); and Ratti (2010) have found out that crime and violence are prevalent in schools and higher learning communities (Burton \& Leoschut, 2013). Research studies have argued that violence on University campuses had always existed. As documented by Schackner (as cited in Pezza, 1995), historians have noted that the situation about safety on campuses of higher educational institutions existed way back in the fifteenth century. The literature has it that bloody and sometimes fatal encounters between townsfolk and students occurred. Also, in 1807, rioting and rebellion resulted in the suspension of more than half of the student population at Princeton University. On another occasion, as documented by Smith (as cited in Pezza, 1995), such acts resulted in the expulsion of a majority of Harvard College's senior class.

In Ghana, it is not uncommon to read about stories of campus violence that sometimes compel student leaders to petition university authorities to solve the problem. For instance, it could be recalled vividly that a group of students of the Common Wealth Hall (Vandals), University of Ghana petitioned the Vice-Chancellor sometime ago on their displeasure about the insecurity on campus. In their petition they cited instances where a level 100 student's laptop was snatched from her and another student was slapped for refusing to hand over her laptop and other valuables when she was attacked by unknown assailants They concluded in their petition by saying, "campus is no safe." 
A news item received from Peace $f m$, a famous local-based Ghanaian station carried a report on $20^{\text {th }}$ February, 2014 that a lifeless body of a Nigerian student of the University of Cape Coast, Mr. Godwin Awogbo was found at Amamoma, an outskirt of the University. (http://www.peacefmonline.com/pages/local/crime/201402/190580.php). According to the station, media briefing with the Commissioner of Police (COP), Prosper Agblorh revealed that when the body was discovered, both hands and legs were tied with a piece of white cloth, the throat slashed and intestines gushing out.

In his bid to add his voice to the causes of insecurity on university campuses, the Member of Parliament (MP) for Asante Akim Central, Hon. Kwame Anyimadu Antwi on $18^{\text {th }}$ July, 2014 in the Chronicle paper attributed the high level of insecurity on our campuses to the influx of foreign students to our tertiary institutions (Adam, 2013).

With all these incidences and comments, it is necessary to find out how students feel about their safety and security. How students perceive security and safety on campus is, therefore, an important issue central to this study.

\subsection{Context of the Study}

The University of Cape Coast (UCC) has over the years been committed to ensuring the safety of her students, faculty, staff, and guests within the catchment area of the University as a way of enhancing their educational experience. UCC's approach to crime prevention and personal safety has often taken the shape of creating awareness among members of her community of a need to take certain precautions. It has, through the many initiatives also emphasised a need to make the individual responsible for their own safety and by extension the safety of others. As an institution, UCC has its own unique approach, consistent with the approach espoused by Xaba (2014) to prevent crime and a mechanism that ensures each of the University's main operating departments is harmonised into an integrated safety network. To give impetus to this issue, the University has a security section which houses security personnel of the institution. In fact, Students' safety at UCC and the safety of each member of the community and visitors is a primary concern which has received and continues to receive urgent attention. The University provides an array of protective measures for students, its faculty and staff. Some of the institutional initiatives aimed at ensuring safety of students include security patrol systems by unarmed security personnel of the university most of whom are not state-certified, and academically-untrained officers. These people are required to patrol every nook and cranny of the campus ensuring law and order in every part of the University campus. The security personnel could be seen throughout the semester twenty-four hours a day, seven days a week. In addition to this arrangement, the security personnel are placed at the main entrances of the University and are required to occasionally conduct search on vehicles which move in and out of the University campus. Perhaps, in order to reinvigorate their activities, the Head of Security meets the personnel to strategise on ways of keeping at bay, activities of miscreants who foment trouble that disturbs peace and security in the university.

At freshmen orientation, the security section clearly outlines security measures that could help students in emergency situations. They are given emergency numbers of the Fire Service (FS), the University Hospital (UH) and the Security Section (SS) to forestall any onto ward occurrence. They could rely on these emergency lines for immediate help. A search at the Directorate of Legal, Consular and General Services at UCC (the Directorate responsible for students' safety issues) revealed that there is no known policy on university visitor and overnight guest rules of conduct which under normal circumstances would help regulate the number of unknown persons who visit the University. Times without number, the security section have had course to advise the university community to pay attention to their own safety, by reporting crime and unsafe conditions, and by helping others.

There are important things students can and are supposed to do and abide by to avoid being a victim of theft or a more serious crime: students especially are often urged to lock their room door when they are asleep or out of their room even when out for a few minutes. They are admonished also not to leave their personal property unattended anywhere that has public access, such as libraries, cafeterias, lecture theatres, and the like. They are always to be aware of their surroundings, whether on or off campus. They are counseled to if possible, walk with friends when out at night as a measure to ensure their own safety and report any suspicious characters immediately to the security section. In our continuing effort to foster a safe and secure environment, UCC has improved its emergency response plan and communication systems with the passing on of vital information to the university community through its radio station, ATL FM. In the event of a crisis, such as a building fire, chemical leak, bomb threat, weather-related hazard, or other potential violence from individuals, the university has not got the ability to simultaneously notify students, faculty, and employees of any looming danger through electronic means and take appropriate actions as other modern universities do. 


\subsection{Statement of the Problem}

University of Cape Coast covers a vast area of land and is surrounded by five communities: Apewosika, Kwesi Pra, Kwapro, Amamoma and Akotokyir. The University has two campuses and inhabitants of these surrounding communities some of who have suspicious character traits sometimes disturb students' peace and security. It is true that university campuses and surrounding areas are frequent targets of thieves, largely because so many students and employees carelessly leave doors unlocked and valuables unprotected. In UCC, most of these people use the University's gates as entry and exit points. The situation has almost encouraged 'bad mannered' people to find themselves everywhere on campus. Past incidences of burglary and other heinous crimes have been perpetuated mostly by these people. This has created insecurity among students who find it extremely difficult to go about their normal academic duties especially when examination approaches. These people take advantage of the intensified learning atmosphere to cash in on the poor students. Despite the seriousness of the issue, it has received little attention from research especially in Ghana. In fact, there is inadequate research evidence in the literature on this important subject hence our motivation to conduct this small scale investigation into the issue to offer solution to address the problem. We foresee that with the increase in violence rates amplified by the media, students are more than aware and are now concerned than ever about their safety on campus.

\subsection{Objectives of the Study}

The study sought to find out student's perception about their safety on University of Cape Coast campus. The study aims specifically to:

1. Find students' perception about their safety on campus through rating:

2. Examine the extent to which students are satisfied with lighting situation on campus

3. Find out specific areas on campus (locations) where students consider the least safe and lastly what suggestions they offer to improve safety and security on campus.

\subsection{Research Questions}

1. How would you rate safety of students on UCC campus during the day and at night?

2. To what extent are you satisfied with the lighting situation on campus?

3. Which places on campus do you not feel safe and at what time of the day?

4. What suggestions do you have for improving safety on UCC campus?

\subsection{Significance of the Study}

This study focuses on students' perceptions of safety and security at the University of Cape Coast. By focusing on student perceptions, this research aims to reveal the types of safety issues students are concerned about, as well as how students perceive safety on campus. Investigating the perception of students on safety on campus is very useful in that the study provides a rich platform to explore the issues on safety and security with a view to helping administrators and University Management alike to address the pressing security issues that confront students through innovative policies.

\section{Literature Review}

In the past decades, a number of studies have focused on issues regarding perceptions of students about their safety on college campuses (Bohmer, \& Parrot, 1993; Brown, \& Andy, 2007; Crawford, O’Dougherty \& Birchmeier, 2008; Kelly \& Alina, 2006). However, there are still gaps in the literature since the field of campus safety is still growing in countries (Chekwa, Thomas \& Jones, 2013). Perception can be explained as a belief or opinion, often held by many people and is usually based on appearances. The subject about campus safety falls within several subfields, with most of the literature relating it to social geography. Safety could be clarified to mean a state in which or a place where one is not in danger or at risk'. It implies in simple terms a situation relatively without of danger and an assurance of freedom from danger, risk, or threat of harm, injury, or loss to personnel and/or property, whether caused deliberately or by accident (Brown \& Andy 2007; Fischman \& Foster, 2007). On campus safety, Volkwein, Szelest, and Lizottet (as cited in Flannery \& Quinn-Leering, 2000) suggested that university campuses are fairly safe learning environments. To them, the communities in which universities are located experience ten times the rate of violent crimes in the university campuses themselves. However, many university students during their stay on campus experience threatening behaviour as victims, perpetrators, or both (Flannery \& Quinn-Leering, 2000).

It is very important to consider campus safety in terms of specific factors in safety perceptions or designing preventative measures, but more information is needed about the overall campus physical environment (Fischman \& 
Foster, 2007). Loukaitou-Sideris and Fink (2009) explore the campus physical environment, stating that certain environmental factors in public settings and their immediate neighbourhoods are generally associated with greater perceptions of fear. More specifically, Loukaitou-Sideris and Fink (2009) found in their study a strong correlation between a run-down physical environment and a perceived fear of that environment. They discovered some factors such as darkness, desolation, lack of other people in surrounding areas, and poor maintenance as variables that influenced perceptions of fear about a public setting though not particularly in a learning environment.

In addition, Loukaitou-Sideris and Fink (2009) describe the specific design characteristics of public space which can influence perceptions of fear, such as places where there are obstructions in one's line of sight, where there are many spaces in which someone could hide, and where one would feel trapped, without possible escape routes. Johnson (2009) defines the physical environment of a campus as the physical space in which campus violence could occur (Burton \& Leoschut, 2013). The social environment delineates, according to Johnson (2009), the nature of interactions, or social norms, that occur among students and other members of the university, within the physical environment of the campus concludes that the social environment of the campus impacts the behaviour of students both at the individual and collective levels. At the individual level, it is the student's individual beliefs, commitments, involvement, and attachment towards the social environment that impacts behaviour. At the collective level, campuses with a cohesive, uniform set of social norms have a social environment which promotes collective action among students. Because the physical and social environments are invariably related to one another, it is important to consider both the campus as physical and social environments when studying campus safety.

Currie (1994) explains that target hardening strategies, which reduce opportunities for crimes to occur, such as better lighting, become the primary means of alleviating concerns if only the physical environment of a campus is considered. Pain (2000) even argues that the social environment operating within particular spaces is more important to perceptions of safety and fear of crime than the physical environment. In any case, it is necessary to consider both the social and physical environment of a campus in order to completely address concerns for campus safety. When thinking about specific incidents, student perceptions of safety vary widely between men and women. For example, Currie (1994) found that a significantly higher number of women reported experiencing threatening incidents on campus than men though this study does not focus on gender on the subject. Also relevant to student perceptions of safety is risk perception literature. Relevant risk perception literature consists of studies which examine specific aspects of campus safety, such as alcohol use or sexual assault.

Many studies report that most students take some type of safety precaution to protect themselves on campus (Brown \& Andy; Currie 1994; 2007; Pain, 2000). These include avoidance strategies (not walking at night, staying away from specific areas of campus), walking with other students, carrying an object which could be used as a weapon, or carrying a weapon. Currie (1994) also found that men and women use safety precautions differently. Men are much more likely to carry a weapon than women, while women are much more likely to use avoidance strategies. Overall, men were much more likely than women to use no safety precautions at all. Starkweather (2007) also found that students may utilise bold strategies to manage their concerns related to campus safety. As a coping strategy, people prefer to act boldly to limit activities of miscreants in response to safety in order to feel safe (Kelly, Turner \& Torres, 2006).

Other studies, including campus security services vary markedly among college campuses, but most studies report campus security providing some form of security patrol, safety escort service, emergency phone system (also known as blue lights), and emergency phone numbers. Fletcher and Bryden (2007) found that the majority of people in their study were aware of campus security and foot patrols, but fewer people had actually used either of these services. Students were much more likely to use avoidance strategies, walk with another person, or use some sort of weapon (including using keys in a defensive manner) than they were to contact campus security or use the foot patrol. Some studies examine what campus security services could do to minimise safety risks to students. According to Franzosa (2009), the most effective way to do this is through encouraging communication between students and campus security services. Franzosa (2009) argues that by communicating that campus security is alert and knows how to react in any situation, students are more likely to be informed and participate in campus safety measures. Students also need to be informed of the risks that exist, without being unnecessarily fearful of the campus. "The key to fighting campus insecurity is not to create fear or diminish freedom, but rather to keep resources available, raise awareness that threats exist, and maintain open lines of communication" (Franzosa, 2009, 21).

This study incorporates insights from the literature to develop campus safety perceptions of undergraduate students in the University of Cape Coast through survey and also provide questions on semi-structured interviews with a view 
to expanding upon findings of previous studies. After a painstaking review of the relevant literature on the subject, researchers derived a simple framework that underlines the study as illustrated on Figure 1.

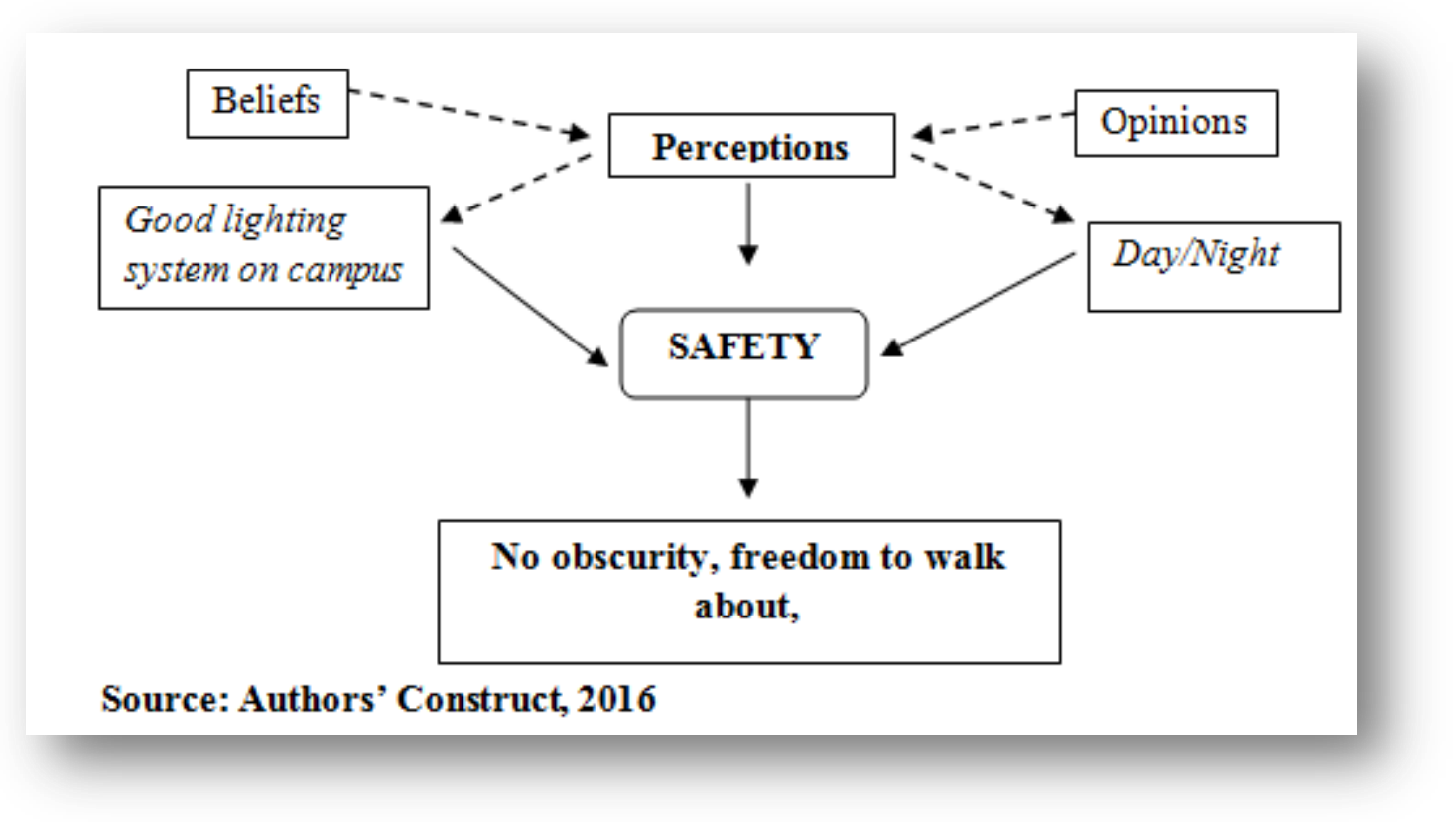

\section{Methodology}

This study used descriptive case study design. The descriptive case study subscribes to the constructivist epistemology which rejects the idea that truth and meaning exist in some external world. On the contrary, this paradigm posits that truth and meaning are created by the individual's interactions with the world. This orientation implies that individuals construct their own meaning in different ways, even in relation to the same phenomenon. Hence multiple methods, contradictory but equally valid accounts of the world can exist (Starkweather, 2007). A theoretical perspective linked to constructivism is interpretivism (Scotland, 2012). This perspective is a major anti-positivist stance which looks for "culturally derived and historically situated interpretations of the social life-world' (Crotty, 1998, p. 67).

The paradigm underlying the study is interpretivism. Ontologically, this position is relativism, the view that reality is subjective and that it differs from person to person (Scotland, 2012; Guba \& Lincoln, 1994, p. 110). Realities of life are mediated by the mind and without awareness, the world is meaningless. Truth surfaces when consciousness engages with objects which are already pregnant with meaning (Crotty, 1998, p. 43). In terms of its theoretical perspective, this study pledges allegiance to the phenomenology which holds that any attempt to understand social reality has to be grounded in people's experiences of that social reality (Chen, Shek, \& Bu, 2011; Carter, \& Little, 2007). Interpretive philosophy is directed at helping to understand phenomenon from an individual's perspective, investigating interaction among individuals as well as the historical and cultural contexts which people inhabit such as case studies (Creswell, 2009, p. 8). The despite its advantages also has certain shortcomings. One of it is the fact that it rejects a foundational base to knowledge, bringing into question its validity. Interpretive research cannot be judged using the same criteria as the scientific paradigm. Legitimacy and trustworthiness need to be achieved without claiming uncontested certainty (Chen, Shek, \& Bu, 2011; Carter, \& Little, 2007). Reaching a consensus is problematic. If reality is subjective and differs from person to person, "then research participants cannot be expected to arrive at exactly the same interpretations as researchers" (Rolfe, 2006, p. 305). Also, knowledge produced by the interpretive paradigm has limited transferability as it is usually fragmented and not unified into a coherent body. Generalisations which are deemed useful to policy makers are often absent because its research usually produces highly contextualised qualitative data and interpretations of this data involve subjective individual constructions (Chen, Shek, \& Bu, 2011; Carter, \& Little, 2007; Berliner, 2002).

Participants' autonomy and privacy can be compromised as the methods of interpretive research are more intimate and open-ended than scientific research. Intimacy and open-endedness may facilitate the unintended discovery of secrets, lies and oppressive relationships (Howe \& Moses, 1999, p. 40). Researchers may have to decide if they have an ethical responsibility to reveal their participants or intervene in their lives, for example, protecting students from 
abusive teachers. Lastly, researchers may have to tone-down their contextualisation in order to protect participants' identities. Participants have limited control and are vulnerable to researchers imposing their own subjective interpretations upon them. Interpretive researchers produce theorised accounts that represent participants' sociological understanding (Danby \& Farrell, 2004). This raises issues of: who owns the data, how will the data be used and how much control over the findings do participants have? Even though participants are often given a voice, it is usually the researcher who decides on: the direction that the research takes, the final interpretation of the data, and which information is made public.

The design enabled the researcher to get a more complete picture of student perceptions of campus safety since most of the earlier studies on campus safety used quantitative design. Other studies including Kelly and Torres (2006), Currie (1994) and Ratti (2010) used a similar methodology. Congruence in the philosophy behind the choice of the design is illustrated by the framework in Figure 2.

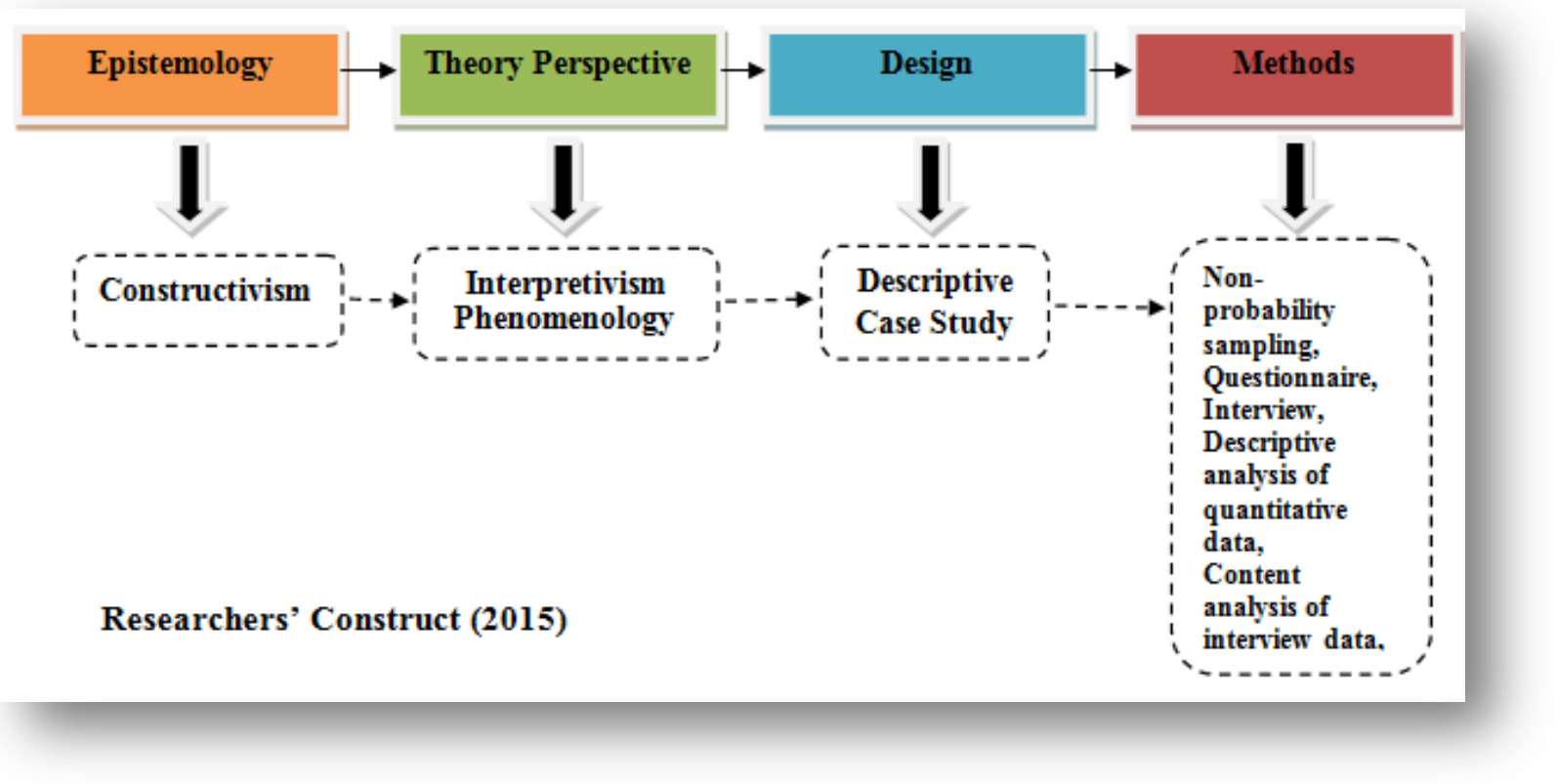

\subsection{Participants}

The population for the study consisted of all undergraduate students on UCC campus offering various academic programmes. To obtain the sample size of 500 students, the researchers used the accidental sampling technique. The accidental sampling, also called convenience sampling involves, "choosing the nearest individuals, in this case students to serve as respondents and continuing that process until the required sample size has been obtained" (Cohen et al., 2007, p.114). In this case, students who happen to be readily available and accessible at the time are sought after and selected at lecture theatres, open spaces where students mostly gather and being at other vantage points where students could easily be identified and included. These students then serve as "captive audiences". The reason for using this procedure lies in the fact that the researchers' interest was not to generalise the findings about the wider population. Also, the convenience sampling technique was used since it coheres well with the study design: the case study (Cohen et al., 2007). In the case of the ten students who were interviewed, the voluntary sampling technique was used to pick student volunteers to be interviewed. The researchers engaged those students who, after completing the questionnaire were again willing to be interviewed. Ten of them, as soon as they were obtained, the search for more students seized and they were used for the interview session. The researchers had to book convenient appointments with them by taking their contact numbers and arranging to meet them. The interview was done after the questionnaire were distributed and collected.

The questionnaire and the interview schedule were tools used to collect data in this study. The questionnaire consisted of three main sections, all of which aim to uncover the beliefs, attitudes, and opinions of students towards campus safety and security services. The first section contains several statements concerning personal beliefs towards campus safety, and respondents were asked to rate their safety both during the day and at night on five-point Likert scale ranging from, excellent, very good, good, bad, worse. The second section asks respondents to rate campus security services and physical features on campus, such as the presence of security personnel and lighting on 
campus. Respondents could select extremely satisfied, satisfied, neutral, dissatisfied, or extremely dissatisfied. The third section of the survey was an open ended question, asking respondents to identify as many as three places where they feel the least safe. Finally, there was also a section which asked the respondent to suggest ways by which University management could improve safety on campus.

Before the questionnaire was administered, it was pilot-tested to determine reliability of the individual items. After the pilot-testing, a Cronbach alpha reliability test was run using the Predictive Analytic Soft Ware (PASW) and a reliability coefficient of 0.78 was obtained. This assured researchers internal consistency of individual items on the safety and security questionnaire. Also based on the feedback received, some portions of the items were reworded to enhance understanding and cohesiveness of the individual items. There was no need for the interview instrument to go through pilot-testing since the interview questions were developed from the questionnaire. The reliability coefficient of 0.78 automatically was a guarantee that the items on the interview were thus also internally consistent and therefore usable.

The researchers administered the questionnaires with the help of a Research Assistant. The interview sessions were conducted by the researchers themselves. Discussions during the interview sessions was recorded and later transcribed. In all, 10 of the respondents were interviewed. The questionnaires were distributed at places where lots of students were found such as at the lecture theatres. In the end, out of the 500 questionnaires which were given out, 467 were completed and returned giving a return rate of $93.4 \%$. ten (10) of the students were randomly picked and interviewed.

\section{Results and Discussion}

\subsection{Biographic Information of Administrator Respondents}

Table 1 and 2 present the demographic characteristics of participants for the study. The variables here include gender and residential status.

Table 1. Distribution of Respondents According to Sex and Hall of Residence

\begin{tabular}{|c|c|c|c|}
\hline Sex & & Number & Percentage (\%) \\
\hline Male & & 283 & 60.6 \\
\hline Female & & 184 & 39.4 \\
\hline Total & & 467 & 100 \\
\hline Residence & & No. of Respondents & $(\%)$ \\
\hline Halls of Residence & & 103 & 22.1 \\
\hline $\begin{array}{l}\text { Private Hostels and } \\
\text { Apartments }\end{array}$ & Rented & 364 & 77.9 \\
\hline Total & & 467 & 100 \\
\hline
\end{tabular}

Out of the 467 students surveyed 283(60.6\%) were males and 184 (39.4\%) were females as shown in Table 1. When asked to disclose their residential status, it was revealed that $103(22.1 \%)$ of the students lived in residential halls whilst $364(77.9 \%$ ) lived in private hostels and rented apartments situated in surrounding villages, thus Apewosika, Kwesi Pra, Amamoma, Akotokyir and Kwapro. The picture paints is that a majority live in rented private apartments where students' security cannot be readily guaranteed. Consequently, it may so happen that these students have heightened concerns about their safety and security since these private places do not have security personnel. This situation on UCC campus contrasts the outcome of a study by Flannery and Quinn-Leering (2000) who suggested that university campuses are fairly safer learning environments. And so for most students on UCC campus, this safety is almost an illusion since they live in their own rented apartments. As Flannery and Quinn-Leering (2000) noted that students in the communities in which universities are located experience ten times the rate of violent crimes compared to the violence in the university campuses (or halls) themselves. Perhaps, this explains why many university students during their stay on campus experience threatening behaviour as victims, or have high perceptions of insecurity. 
Research Question 1: How would you rate the safety of UCC campus during the day?

Table 2. Students' Rating of their Perceived Safety During the Day and at Night

\begin{tabular}{lll}
\hline RATINGS & $\begin{array}{l}\text { DAY } \\
\text { No of respondents (\%) }\end{array}$ & $\begin{array}{l}\text { NIGHT } \\
\text { No of respondents / (\%) }\end{array}$ \\
\hline Excellent & $4(.9)$ & $0(0)$ \\
Very Good & $292(62.6)$ & $11(2.3)$ \\
Good & $124(26.5)$ & $22(4.7)$ \\
Bad & $14(3.0)$ & $344(7.4)$ \\
Worse & $33(7.0)$ & $90(19.3)$ \\
Total & $467(100)$ & $467(100)$
\end{tabular}

Examining the personal beliefs of students concerning safety on campus both during the day and at night, the overall results of the survey show that $416(89.1 \%$ ) of students surveyed believe that their safety on UCC campus was good during the day. The same could not be said about the night as 413(88.4\%) considered their safety on campus as bad. The study revealed that majority of the students who felt the least safe on campus during the night was non-residential students. researchers can state therefore that students perception of safety on UCC campus is to a large extent dependent on what time of the day it is and which part of campus they lived, residential or non residential. This finding somewhat concurs with the work conducted by Loukaitou-Sideris and Fink (2009). This work (study) explored and discovered factors such as darkness, desolation, lack of other people in surrounding areas, and poor maintenance as variables that influenced perceptions of fear about a public setting though not particularly in a learning environment.

\section{Research Question 2: To what extent are you satisfied with the lighting situation on campus?}

Table 3. Students' Perceived Satisfaction about the Lighting Situation on Campus

\begin{tabular}{lll}
\hline & Number of respondents & Percentage (\%) \\
\hline Extremely Satisfied & 7 & 1.5 \\
Satisfied & 12 & 2.6 \\
Neutral & 0 & 0 \\
Extremely Dissatisfied & 101 & 21.6 \\
Dissatisfied & 347 & 74.3 \\
Total & 467 & $100 \%$
\end{tabular}

When asked about their satisfaction about the lighting situation on campus, 448(95.9) of them were not satisfied with the lighting situation on campus. It appears that the breakdown in the lighting infrastructure on campus in recent times has culminated in the poor situation. Again, this outcome is similar to the findings by Loukaitou-Sideris and Fink (2009) in which they found a strong correlation between a run-down physical environment and a perceived fear of that environment. For them, once the physical infrastructure in any environment suffers reparations thereby affecting functionality output, people begin to perceive this place as highly unsafe again for human habitation. In this case, the poor maintenance culture becomes a variable that influences students' perceptions of fear.

\section{Research Question 3: Which places on campus don't you feel safe and at what time of the day?}

With regard to the areas they feel the least safe at night; a majority of students mentioned the following as areas or locations where they feel very insecure with varying occurrence: School Bus Road (38\%); Congregational Grounds (47\%); Summer huts (49\%); and Science Roof Top (32\%). The rest include Cafeteria Roof Top (31.6\%); Road from Valco Hostel to Kwaprow (66\%); Ayensu road (51\%); and Road to College of Education (38\%). The rest are the Science Garden; Road leading to SNNIT hostel; Road leading from main library to Sasakawa; and Parliament House. 
The finding is similar to aspects of the issues that were explored by Ratti (2010) which covertly suggested that people feel very insecure being at certain places in the environment compared to other places.

\section{Research Question 4: What suggestions do you have for improving safety on UCC campus?}

The study got information to answer this research question through the use of interviews. A majority of the student interviewees suggested that more hostel facilities should be provided by the University. Again, they indicated that emergency phone lines should be made available on campus and that security presence on campus should be increased. The students suggested that proper monitoring be done on the security personnel to ensure that those at post do their work effectively. The interviewees among other things also indicated that proper screening should be conducted on people especially, visitors and community folks who go in and out of campus. As a measure to ensure safety, students and staff should wear their ID cards as tags to identify them. On street lights, a majority of the students suggested that extra street lights be procured and added and measures taken to replace spoilt ones. They recommended for more education to be done on security issues and emergency phones also made available for students. Finally, the majority suggested that security cameras should be fixed at certain areas on campus.

The findings from the interviews support the results of the survey as respondents overwhelmingly expressed that they usually feel very safe on campus during the day but not at night. One of the respondents puts it this way: 'I feel safe during the day but not at night. Because of this, I avoid walking alone in the night'. In response to the same question, another respondent said: 'I am not so careful when I am walking around campus during the day; perhaps it is because a lot of people are around during the day. At night, I am careful about which areas I pass'. Yet still, a third respondent remarked: 'Although, there are not many controls as to who enters and leaves campus, I have never felt unsafe on campus during the day'.

A majority of the interviewees indicated that they were not happy with the lighting situation on campus especially when the lights are out. They advised that street lights that used solar should be fixed. Majority of the interviewees indicated that security personnel on campus were ill equipped and because of this they do not feel so confident reporting certain incidences to them when they are danger. Apart from asking general questions about perceptions of campus safety, the researchers asked few specific questions. The first of these was whether students were aware of the campus emergency numbers such as the Fire Service, the Security Service and the University Hospital. Although most of the interviewees admitted that these emergency numbers had been given to them during their orientation programme and may be in some documents given to them, they admitted they had not committed these numbers into memory.

The next question was the opinion of interviewees about the springing up of alcoholic joints around campus and how they believed it affected their safety. Respondents agreed that this could affect their safety as some students may go to such spots, get drunk and behave violently on campus. They were, however, quick to admit that since it is generally believed anyone who gains admission to the university is an adult and could think for himself/herself, students cannot be stopped from going to such spots. Rather what they think should be done is that security personnel should be well equipped to deal with students who may engage in violent acts and appropriate sanctions be applied to the latter. When asked about their safety with regard to a fire explosion, most of the interviewees expressed concern. They indicated that although the University authorities are doing much to discourage the use of liquefied petroleum gas in the halls of residence, most students are adamant.

\subsection{Recommendations/ Administrative Implications}

For the university student who is navigating a balance between academic work and being independent for the first time in his or her young adult life, the university is a myriad of confusion as they grapple to find their way, and need to know that they are safe on campus. It is recommended therefore that first, University Management places at the centre efforts to improve the lighting situation on campus, especially at areas where students consider unsafe. The peculiar nature of the UCC campus requires that active steps be taken to build more halls of residence to safeguard the life of students. The findings from this study revealed that students in the halls of residence felt safer than those in private hostels and rented apartments in the surrounding communities. Thirdly, the professionalization of the campus security services should be a priority area in the strategic direction of the University. Going forward, equipping the campus security with all the appropriate and necessary logistics for their work and increasing their presence at perceived unsafe areas should be one on the strategies to build confidence in management's ability to guarantee the safety and security of students and all others who work at the University. 


\section{Conclusion}

Securing an environment for learning and making it safe requires an all-inclusive approach that does not only address unhelpful behaviour (such as people with a penchant for violence and bullying) but also tackle the basic elements of the school environment to curb such tendencies. So creating a safe and secure school requires dealing with the whole school environment consisting of the physical and psychosocial environments. It can also be inferred that addressing the physical environment of the school lays a firm foundation for dealing with various psychosocial threats that commonly plaque our universities. Clearly, the issue of safety on university campuses cannot be ignored and it is high time the university management took steps to ensure that students felt safe on campus to go about their learning without fear. No matter how effective the University's programmes may be the primary responsibility for safety and security lies with each one within the university community. No security department or set of procedures can be effective unless individuals exercise reasonable care and prudence. Safety and security is everyone's responsibility. UCC maintains its own security force. The UCC security department should begin thinking about recruiting competent professional staff. The University should also begin to think about resourcing the security staff with the right kind of modern equipment necessary to fight crime. There is a need for collaboration between the state police service, the Ghana military and the security department of the university to synergise their activities to fight crime and ensure the safety of students. It should be possible for the University security department to sign a memorandum of understanding with other para-security agencies such as the Ghana fire service, the prisons service among others for immediate mutual assistance.

\section{References}

Adam, F. (2013). Foreign students contributing to insecurity in hostels -MP. Retrieved from: http://thechronicle.com.gh/foreign-students-contributing-to-insecurity-in-hostels-mp/.

Berliner, D. C. (2002). Educational research: The hardest science of all. Educational Researcher, 31(8), 18-20. http://dx.doi.org/10.3102/0013189X031008018.

Bohmer, C. \& Andrea P. (1993). Sexual assault on campus: The problem and the solution. New York: Lexington Books.

Brown, S. L. \& Andy, M. M. (2007). Risk perception, fuzzy representations and comparative optimism. British Journal of Psychology, 98, 575-578. http://dx.doi.org/10.1348/000712606X169020

Burton P., \& Leoschut L. (2013). School violence in South Africa: Results of the 2012 National School Violence Study. Cape Town: Centre for Justice and Crime Prevention, Monograph Series, No 12. March.

Carter, S. M. \& Little, M. (2007). Justifying knowledge, justifying method, taking action: Epistemologies, methodologies, and methods in qualitative research. Qualitative Health Research, 17(10), 1316-1328. http://dx.doi.org/10.1177/1049732307306927

Chekwa, C., Thomas, T. J. \& Jones, J. J. (2013). What are college students' perceptions about campus safety? Contemporary Issues in Education Research, 6(3), 325 -332. http://dx.doi.org/10.19030/cier.v6i3.7903

Chen, Y. Y., Shek, D.T. \& Bu, F. F. (2011). Applications of interpretive and constructionist research methods in adolescent research: Philosophy, principles and examples', International Journal of Adolescent Medicine and Health, 23(2), 129-139. http://dx.doi.org/10.1515/ijamh.2011.022

Crawford, E. W., O'Dougherty, M., \& Birchmeier, Z., (2008). Drug-facilitated sexual assault: College women's risk perception and behavioral choices. Journal of American College Health, 57(3), 261-274. http://dx.doi.org/10.3200/JACH.57.3.261-272

Creswell, J. W. (2009). Research design: Qualitative and mixed methods approaches. London: Sage.

Crotty, M. (1998). The foundation of social research: Meaning and perspectives in the Research Process. London: Sage.

Currie, D. H. (1994). Women's safety on campus: Challenging the University as gendered space. Humanity \& Society, 18(3), 24-47.

Danby, S., \& Farrell, A. (2004). Accounting for young children's competence in educational research: New perspectives on research ethics. The Australian Educational Researcher, 31(3), 2004. http://dx.doi.org/10.1007/BF03249527.

Flannery, D. J., \& Quinn-Leering, K. (2000). Violence on college campuses: Understanding its impact on student well-being. Community College Journal of Research \& Practice, 24(10), 78 - 92. 
Fernandez, M. (2001). Crime prevention and the perception of safety in campus design. Unpublished thesis, Louisiana State University.

Fischman, J., \& Foster, A. L. (2007). Campus safety gains sharper vision with new breed of surveillance cameras. Chronicle of Higher Education, 53(34), 13 - 25.

Fletcher, P. C., \& Bryden, P. J. (2007). Preliminary examination of safety issues on a university campus: Personal safety practices, beliefs, and attitudes of female faculty and staff. College Student Journal, 41(4), 1149-1162.

Franzosa, A. (2009). Insecure? Keeping New England college campuses safe from violence. New England Journal of Higher Education, 20-21.

Frowe, I. (2001). Language and educational research. Journal of Philosophy and Education, 35(2), 175-186. http://dx.doi.org/10.1111/1467-9752.00219.

Gorry! Student murdered at UCC campus, (2014, February 20). Peacefmonline.com. Retrieved from http://www.peacefmonline.com/pages/local/crime/201402/190580.php.

Guba, E. G., \& Lincoln, Y. S. (1994). Competing paradigms in qualitative research. In N.

K. Denzin, \& Y. S. Lincoln (Eds.), Handbook of qualitative research. p. 105-117. London: Sage.

Howe, K. R. (2009). Epistemology, methodology and education sciences. Positivist dogmas, rhetoric, and the education science question. $\quad$ Educational Researcher, 38(6), 428-440. http://dx.doi.org/10.3102/0013189X09342003

Howe, K. R., \& Moses, M, S. (1999). Ethics in educational research. Review of Research in Education, 24, 21-59. http://dx.doi.org/10.3102/0013189X09342003

Johnson, S. L. (2009). Improving the school environment to reduce school violence: A review of the literature. Journal of School Health, 79(10), 451-65. http://dx.doi.org/10.1111/j.1746-1561.2009.00435.x

Kelly, B. T. \& Torres, A. (2006). Campus safety: Perceptions and experiences of women students. Journal of College Student Development, 47(1), 20-35. http://dx.doi.org/10.1353/csd.2006.0007

Loukaitou-Sideris, A. \& Fink, C. (2009). Addressing women's fear of victimisation in transportation settings. Urban Affairs Review, 44(4), 554-587. http://dx.doi.org/10.1177/1078087408322874

Pain, R. (2000). Place, social relations and the fear of crime: A review. Progress in Human Geography, 24(3), 365-387. http://dx.doi.org/10.1191/030913200701540474

Pezza, P. E., \& Bellotti, A. (1995). College campus violence: Origins, impacts, and responses. Educational Psychology Review, 7(1), 49 - 62. http://dx.doi.org/10.1007/BF02214209

Ratti, L. C. (2010). Student perception of campus safety at University of Mary Washington. A thesis submitted in partial fulfillment for Honours in Geography, University of Mary Washington.

Rolfe, G. (2006). Validity, trustworthiness and rigour: Quality and the idea of qualitative research. Journal of Advanced Nursing, 53(3), 304-310. http://dx.doi.org/10.1111/j.1365-2648.2006.03727.x.

Scotland, J. (2012). Exploring the philosophical underpinnings of research: Relating ontology and epistemology to the methodology and methods of the scientific, interpretive, and critical research paradigms. English Language Teaching, 5(9), 9 - 16. http://dx.doi.org/10.5539/elt.v5n9p9

Starkweather, S. (2007). Gender, perceptions of safety and strategic responses among Ohio university students, $A$ Journal of Feminist Geography, 14(3), 355-370. http://dx.doi.org/10.1080/09663690701325000

Xaba, M. I. (2014). A holistic approach to safety and security at schools in South Africa. Mediterranean Journal of Social Sciences, 5(20), $1580-1589$. 